\title{
ANALISIS KESALAHAN MORFOLOGI PADA PIDATO PRESIDEN JOKO WIDODO DALAM RANGKA PELANTIKAN PRESIDEN DAN WAKIL PRESIDEN TERPILIH PERIODE 2019-2024
}

\author{
Kurnia Saputri \\ Universitas Pembangunan Nasional "Veteran" Yogyakarta \\ E-mail: saputrikurnia31@gmail.com
}

\begin{abstract}
Presidential Regulation Number 16 of 2010 concerning the obligation to use Indonesian in official speech activities by the president and/or vice president and other state officials. Therefore, as president, he must pay attention to the use of Indonesian when giving speeches. The president's speech will be heard by so many people that a president and other officials must set a good example to the public. Often we still hear some morphological mistakes in the president's speech, such as still mixed with the dialect of the region. There is nothing wrong if we correct some of the morphological errors of the words spoken by the president.
\end{abstract}

Keywords: Presidential speech, morphological errors

\begin{abstract}
Abstrak: Peraturan Presiden Nomor 16 Tahun 2010 tentang kewajiban menggunakan bahasa Indonesia dalam kegiatan berpidato resmi oleh presiden dan/atau wakil presiden serta pejabat negara lainnya. Maka dari itu, sebagai presiden harus memperhatikan penggunaan Bahasa Indonesia saat berpidato. Pidato presiden akan didengar oleh banyak orang sehingga seorang presiden dan pejabat lainnya harus memberi contoh yang baik kepada masyarakat. Sering kali kita masih mendengar beberapa kesalahan morfologi dalam pidato presiden, seperti masih tercampur dengan logat daerahnya. Tidak ada salahnya jika kita mengoreksi beberapa kesalahan morfologi kata yang diucapkan oleh presiden.
\end{abstract}

Kata Kunci : Pidato presiden, kesalahan morfologi

\section{PENDAHULUAN}

Pidato merupakan cara seseorang untuk menyambut sesuatu atau memberikan informasi di depan umum secara lisan. Pidato begitu penting digunakan dalam acara resmi maupun acara yang diselenggarakan hanya untuk hiburan. Pelaku pidato biasanya adalah seseorang yang penting seperti pemimpin, presiden, kepala sekolah, atau yang mewakili suatu kelompok. Oleh sebab itu, orang yang mau berpidato harus mempirsiapkan diri sebaik mungkin agar tercapai apa yang diharapkan. Tidak semua orang di dunia ini memiliki keterampilan berpidato. Berbicara di muka umum biasanya dilakukan oleh seseorang yang telah dikenal oleh kelompoknya sebagai orang yang terlatih dalam berkomunikasi. Orang yang terlatih berkomunikasi dengan orang banyak lebih sering ditunjuk untuk menyampaikan pidato mewakili kelompoknya. Sehingga orang yang terlatih berbicara ini bisa meyakinkan pendengar tentang tujuan kelompok tersebut di acara yang diselenggarakan. Seseorang berpidato perlu memperhatikan beberapa kata yang diucapkan, terkadang masih terdapat orang Indonesia ketika berpidato tidak 
memakai bahasa Indonesia dengan sesuai. Padahal kaidah dalam berpidato sangatlah penting supaya acara dapat berjalan dengan lancar dan juga lebih berkesan menghormati pendengar pidato.

Pidato yang sering menjadi sorotan seluruh rakyat Indonesia adalah pidato resmi presiden Joko Widodo. Presiden Joko Widodo merupakan seseorang yang sangat terpandang di Indonesia sehingga setiap perkataannya diperhatikan oleh banyak orang termasuk dari negara lain. Kesalahan sedikit saja ketika berpidato bisa menjadi bahan perdebatan banyak orang. Oleh karena itu, seorang presiden ketika berpidato harus memperhatikan setiap kata yang diucapkan serta cara berpidato yang baik dan benar.

\section{PROSES MORFOLOGI}

Tarigan (dalam Widyastuti, 2015) mengemukakan bahwa morfologi ialah ilmu bahasa yang membahas tentang pembentukan kata serta pengaruh perubahannya terhadap klasifikasi dan makna kata. Morfologi dalam bahasa Indonesia (KBBI,2016) adalah cabang linguistik mengenai morfem dan jenis-jenisnya.

Menurut (Hassan, 2006), Morfem ialah unit bahasa yang terkecil mempunyai makna atau fungsi tata bahasa. Keraf (dalam Widyastuti, 2015) membedakan morfem menjadi dua kelompok yaitu morfem yang telah memiliki makna sendiri tanpa harus digabung dengan morfem lain disebut morfem bebas, sedangkan morfem yang harus digabung dengan morfem lainnya disebut morfem terikat. Morfem bebas sudah dapat diartikan sebagai kata. Morfem terikat dibagi menjadi dua yaitu morfem pradasar dan klitik. Morfem pradasar adalah gabungan morfem yang memiliki makna, misalnya panca dan sila. Morfem klitik adalah morfem yang harus digabungkan dengan kata kerja supaya menghasilkan makna, misalnya ter-, ber-, per-, -kan, -an, -i, men-, meng-, menge-, menye-, mem-, ke-/-an, pe-/-an, me-/-kan, $m e-/-l$, dan lain-lain.

\section{KARAKTERISTIK KESALAHAN MORFOLOGI}

Menurut Setyawati (dalam Mutiadi, 2015), ada beberapa kesalahan pengucapan kata secara morfologi yaitu : pemakaian afiks yang tidak sesuai, bunyi huruf yang seharusnya luluh tetapi tidak diluluhkan, penghilangan afiks, penghilangan prefiks, penggantian morf, pembentukan kata dasar yang tidak tepat, peluluhan bunyi huruf yang seharusnya tidak diluluhkan, dan morf yang disingkat menjadi mem-, men-, meng-, meny-, dan menge-. Menurut (Cembes, 2018), Afiks merupakan imbuhan terikat dan tidak dapat berdiri sendiri sehingga selalu berdampingan dengan kata dasar. Dalam proses afiksasi terdapat lima jenis bentuk yaitu prefiks, infiks, sufiks, konfiks, dan simulfiks. Prefiks adalah imbuhan yang mengawali sebuah kata dasar. Jenis-jenis prefiks meliputi men-, ber-, di-, ter-, pen-, per-, ke-, dan se-. Infiks merupakan imbuhan yang terletak di dalam kata atau bisa disebut sebagai sisipan. Jenis imbuhan ini pemakaiannya terbatas hanya pada kata- 
kata tertentu. Jenis-jenis infiks meliputi -er-, -el-, -em-, dan -in-. Sufiks merupakan akhiran yang biasa diletakkan pada akhir kata dasar. Jenis-jenis sufiks meliputi -kan, -i, dan -an. Konfiks merupakan dua morfem yang diletakkan sekaligus pada bentuk dasar. Jenis-jenis konfiks meliputi ke-an, ber-an, per-an, pen-an, dan se-nya. Simulfiks merupakan imbuhan yang diletakkan secara bersamaan pada bentuk dasar. Jenisjenis simulfiks meliputi mem-per-i, mem-per-kan, di-per-i, dan di-per-kan. Kesalahan yang sering terjadi adalah penghilangan afiks misalnya pada kalimat "mereka yang bakat di bidang seni". Kata bakat dalam kalimat tersebut salah, seharusnya adalah berbakat. Pemakaian afiks yang tidak tepat biasanya terjadi akibat kekurangcermatan seseorang dalam membaca kata. Misalnya pada kalimat "mereka terkorban di medan peperangan". Kata terkorban dalam kalimat tersebut tidak baku, seharusnya adalah "mereka berkorban di medan peperangan".

Menurut (Purwaningsih, 2016), fonem /k/, t/, /s/, dan /p/ ketika mendapat imbuhan meN- dan peN- akan luluh menjadi bunyi seperti mengeluarkan udara dari hidung atau disebut anuswara. Misalnya fonem /p/ menjadi /m/. /s/ menjadi /ny/, /k/ menjadi /ng/, dan /t/ menjadi /n/. Kata dasar yang memiliki awalan berhuruf $/ \mathrm{k} / \mathrm{s} / \mathrm{t} / \mathrm{s} / \mathrm{s}$, dan $/ \mathrm{p} /$ akan melebur jika huruf ke dua berupa huruf vokal. Misalnya: menyimpan (simpan), menyapu (dari kata sapu), dan memukul (dari kata pukul). Jika huruf kedua berupa huruf mati maka tidak akan melebur. Misalnya: mentraktir (dari kata traktir), mengkritik (dari kata kritik), dan mengkristal (dari kata ktistal). Menurut ( A'yuni, 2013), kata dasar yang berfonem awal bunyi /c/ seharusnya tidak luluh jika mendapat prefiks men-. Kesalahan peluluhan huruf /c/ kemungkinan disebabkan oleh pengaruh logat daerah asal. Misalnya pada kata nyari (dari kata cari) seharusnya kata dasar yang berawalan huruf /c/ diawali dengan prefiks menbukan prefik ny-, sehingga kata yang benar adalah mencari.

Herman (dalam A'yuni, 2013) menjelaskan bahwa morf merupakan bagian dari bentuk kata yang mewakili suatu morfem terntenu. Kesalahan yang sering terjadi yaitu ketika morf menggantikan morf yang lainnya. Penggantian morf bemenjadi morf ber- sering dijumpai dalam pengucapan baik secara sadar maupun tidak sadar. Misalnya pada kata berpergian (kata dasar pergi) seharusnya yang baku adalah bepergian karena terdapat huruf /r/ pada kata pergi sehingga tidak memakai morf ber-. Mungkin kesalahan ini juga sering terjadi akibat kurang pahamnya seseorang dalam membentuk kata yang berimbuhan. Penyingkatan morf juga sering terjadi, misalnya kesalahan penulisan kata ngambil, morf meng- disingkat penulisannya menjadi ng- saja supaya terlihat lebih singkat. Kata ngambil memiliki kata dasar yaitu ambil, sehingga kata yang benar adalah mengambil.

Penentuan bentuk dasar tidak tepat, misalnya pada bentukan kata ditulisin. Kata ditulisin terinspirasi dari bahasa gaul yang sering diucapkan oleh kalangan muda. Kata ditulisin berasal dari kata dasar tulis sehingga lebih tepat jika dirangkai dengan konfiks di-...-kan maka akan kata dituliskan. Dituliskan memiliki arti menulis namun dilakukan oleh orang lain. 


\section{KESALAHAN MORFOLOGI PIDATO PRESIDEN JOKO WIDODO}

Pada tanggal 20 Oktober 2019, kita telah menyaksikan pelantikan presiden Joko Widodo (Jokowi) sebagai preside ke-7 Indonesia. Acara tersebut menandai dimulainya kinerja Joko Widodo pada periode kedua dan pertama kalinya Ma`ruf Amin menjadi wakil presiden. Seusai pelantikan, seorang presiden akan membacakan pidatonya dengan disaksikan oleh seluruh rakyat Indonesia. Pidato presiden Jokowi menjadi sorotan rakyat Indonesia dan juga mancanegara. Ada beberapa kesalahan pengucapan dalam pidato presiden Jokowi seperti penghilangan prefiks se-, penghilangan prefiks ber-, penentuan kata tidak tepat, penghilangan sufiks - an, kalimat tidak efektif, dan penggunaan kata tidak baku.

Penghilangan prefiks se- pada kata harus dalam kalimat Harusnya, inovasi bukan hanya pengetahuan. Inovasi adalah budaya. Kata yang benar adalah seharusnya. Kalimat tersebut juga tidak efektif karena konjungsi bukan hanya seharusnya berpasangan dengan kata melainkan. Konjungsi bukan hanya...melainkan merupakan salah satu konjungsi korelatif. Menurut (Pesik, 2016), konjungsi korelatif adalah kata penghubung yang menghubungkan dua kalimat setara atau lebih menjadi satu kalimat utuh. Penghilangan prefiks ber-pada kata bisik-bisik dalam kalimat "Langsung saya bisik-bisik" seharusnya yang benar adalah berbisik-bisik. Prefiks ber- untuk menyatakan melakukan sesuatu. Penghilangan sufiks -an pada kata jawabnya dalam kalimat Kalau ditanya, jawabnya "Programnya sudah terlaksana, Pak." seharusnya yang benar adalah jawabannya. Kalimat tidak efektif seperti preposisi di awal kalimat Para hadirin dan seluruh rakyat Indonesia yang saya banggakan. Kata hadirin sudah berarti jamak sehingga tidak perlu ditambahkan kata para. Kata tidak baku seperti kata tapi dalam kalimat Tapi akan menjadi kesempatan besar, peluang besar, jika kita mampu membangun SDM yang unggul. Menurut (KBBI, 2016) kata tapi merupakan bentuk tidak baku tetapi, namun untuk acara formal lebih baik memakai kata tetapi. Penentuan kalimat tidak tepat dalam kalimat apa enggak kebanyakan? Padahal ada bentuk yang lebih tepat yaitu apa tidak terlalu banyak?

\section{KESIMPULAN}

Berpidato merupakan suatu kegiatan menyampaikan informasi atau pernyataan di muka umum dengan tujuan tertentu. Berpidato dilakukan oleh seseorang untuk mewakili kelompoknya. Salah satu pidato yang terkenal di Indonesia adalah pidato kenegaraan presiden Joko Widodo dalam rangka pelantikan presiden periode 2019-2024. Ada beberapa kata dan kalimat yang diucapkan belum sesuai dengan bentuk baku dalam bahasa Indonesia, namun pidato beliau sudah cukup bagus. Berpidato di muka umum selain menyatakan pendapat, kita juga harus memperhatikan setiap kalimat yang kita ucapkan. Banyak kesalahan yang terjadi saat berpidato seperti penggantian morf, penghilangan afiks, 
pembentukan afiks yang tidak sesuai, bentuk dasar yang tidak sesuai, peluluhan bunyi huruf yang seharusnya tidak diluluhkan, kesalahan penyingkatan morf mem, men-, meng-, meny-, dan menge-, bunyi huruf yang seharusnya luluh tetapi tidak diluluhkan, dan penghilangan prefiks. Maka dari itu, sebelum berpidato sebaiknya melakukan latihan terlebih dahulu dan meneliti kembali kalimat yang akan disampaikan.

\section{DAFTAR PUSTAKA}

A'yuni, N.B., dkk. (2013). Analisis Kesalahan Berbahasa Tataran Morfologi dalam Skripsi Mahasiswa PBSI IKIP PGRI Madiun Tahun Akademik 2013/2014. Ilmiah.

Cembes, M.A. (2018). Analisis Kesalahan Penggunaan Afiks Pada Artikel Opini Surat Kabar Kedaulatan Rakyat Edisi Januari -April 2017. Skripsi.Yogyakarta: Repository USD.

Hassan, P.E. (2006). Morfologi. Kuala Lumpur : PTS Professional Publishing Sdn. Bhd.

Kemendikbud. (2016). Kamus Besar Bahasa Indonesia. Jakarta: Badan Pengembangan dan Pembinaan Bahasa.

Mutiadi, A.D. \& Indah Patimah. (2015). Analisis Kesalahan Morfologis dan Sintaksis Pada Pidato Presiden Joko Widodo Periode Januari 2015. Ilmiah.

Pesik, V. (2016). Konjungsi Dalam Novel Pride and Prejudice Karya Jane Austen. Skripsi.

Purwaningsih, S. (2016). Kesalahan Berbahasa Bidang Fonologi dan Morfologi dalam Penulisan Surat Dinas di SMK Harapan Kartasura. Ilmiah.

Widyastuti. (2015). Proses Pembentukan Nomina Bahasa Muna Dialek GU-MAWASANGKA. Humanika, 3(15), 1-14.

Peraturan Presiden Nomor 16 Tahun 2010 tentang penggunaan bahasa Indonesia dalam pidato resmi Presiden dan/atau Wakil Presiden serta pejabat negara lainnya. 